in the neonate. Archives of Disease in Childhood 1975; 50: 81-3.

5. Pedroso FS, Rotta N, Quintal A, Giordani G. Evolution of anterior fontanelle size in normal infants in the first year of life. Journal of Child Neurology 2008; 23: 1419-23.

6. Mathur S, Ram K, Mathur GP, et al. Anterior fontanel size. Indian Pediatrics 1994; 31: 161-4.

7. Shajari H, Rashidiranjbar N, Ashraf M. Anterior fontanelle size in healthy Iranian neonates on the first day of life. Acta Medica Iranica 2011; 49: 543-6.

8. Duc G, Largo RH. Anterior fontanelle: size and closure in term and preterm infants. Pediatrics 1986; 78: 904-8.
9. Department of Census and Statistics, Sri Lanka. Population and Housing, 2010.

10. Rennie JM. Roberton's Text Book of Neonatology. 4th edition. London: Elsevier, 2005.

11. Pillitteri A. Maternal and Child Health Nursing. Philadelphia: Lippincott Williams \& Wilkin, 2010.

12. Raiti S, Newns GH. Cretinism: early diagnosis and its relation to mental prognosis. Archives of Disease in Childhood 1971; 46: 692-4.

13. Smith DW, Popich G. Large fontanelles in congenital hypothyroidism: A potential clue towards earlier recognition. Journal of Pediatrics 1972; 80: 753-6.

\title{
Incidence and risk factors of falls among the elderly in the district of Colombo
}

\author{
A D Ranaweera ${ }^{1}$, P Fonseka ${ }^{2}$, A PattiyaArachchi ${ }^{3}$, S H Siribaddana ${ }^{4}$
}

(Index words: elderly, falls, incidence, risk factors)

\begin{abstract}
Objectives To assess the incidence and risk factors of falls among the elderly in the District of Colombo.

Methods Incidence of falls was assessed by a community based descriptive study with prospective follow up. Risk factors for falls were assessed by a nested case control study. Participants above 65 years residing in 40 Grama Niladhari Divisions in the Colombo district $(n=1200)$ were assessed for falls and followed up for four months. Those who had falls were selected as cases $(n=151)$, while two controls per case were selected from others.

Measurements Tests for gait problems, disability, cognitive impairment and vision.

Results The incidence rate of falls was 492 per 1000 person years $(95 \% \mathrm{Cl} 448-536)$. Risk factors for falls identified in the multivariate analysis were falls in the previous year (OR 4.67), high disability level (OR 2.04) and high house risk level (OR 1.68).

Conclusions The high incidence of falls among the elderly reported in this study and the preventable risk factors identify / indicate the necessity and feasibility of their prevention.
\end{abstract}

Ceylon Medical Journal 2013; 58: 100-106

\section{Introduction}

The Sri Lankan population is ageing rapidly. In 2001, $10 \%$ of Sri Lankans were over 60 years old and by 2030 it is expected to be $22 \%$ [1]. Falls are a leading cause of disability and death in the elderly [2]. Each year 28-35\% of people over 65 years and 32-42\% of people over 70 years fall [3]. The frequency of falls increases with age and frailty. Incidence of falls in United Kingdom, China and Japan are $22.4 \%, 19.3 \%$ and $20 \%$ per year respectively [3, 4]. In India the frequency of falls over six months was $14 \%$.

Falls in the elderly result in fractures: mainly in hip, spine, arms, ankles, and legs [6]. The strongest single risk factor for fractures is falls not osteoporosis [7]. Falls are predictable and preventable, but if no precautions are taken, falls can occur repeatedly [8]. There is evidence that a number of interventions prevent falls [9].

Information on falls in the elderly is limited in Sri Lanka as well as other developing countries. A hospital based study of elderly in the district of Colombo found that, $23 \%$ of the people who were over 65 years fell in a year [10]. A hospital based study on hip fracture in the same district recommended community based studies on falls [11]. This study was conducted to assess the

\footnotetext{
${ }^{1}$ Postgraduate Institute of Medicine, Colombo, ${ }^{2}$ Department of Community Medicine, Faculty of Medical Sciences, University of Sri Jayawardanepura, ${ }^{3}$ National Hospital of Sri Lanka and ${ }^{4}$ Department of Medicine, Faculty of Medicine and Allied Sciences, University of Rajarata, Sri Lanka.

Correspondence: ADR, e-mail: <dranaweera90@gmail.com>. Received 7 January 2013 and revised version accepted 9 February 2013. Competing interests: none declared.
} 
incidence and risk factors of falls among elderly in the Colombo district.

\section{Methods}

\section{Participants and setting}

This study was conducted from August 2010 to March 2011. Participants were over 65 years of age, residing in the Colombo district, and walking independently or with an aid. Institutionalised and critically ill participants were excluded. Sample size calculation indicated that a minimum sample of 1200 participants would be required as the baseline population to get the minimum number of cases, i.e. participants with falls $(n=115)$ required for the nested case control study [12].

Multistage cluster sampling method was used and clusters were allocated by probability proportional to size method. Considering the logistic factors and the time taken for the interview, 30 participants were taken as the cluster size. The required 1200 participants were selected from 40 out of 557 Grama Niladhari divisions (GN) in the Colombo district $(1200 / 30=40)$. People over 65 years were classified into urban and rural sectors using the classification of GN divisions (2010) obtained from the Statistics Division of the Colombo District Secretariat. Distribution of population over 65 years according to GN divisions was obtained from the Census Report, 2001. The number of clusters in each sector was determined by multiplying the total number of clusters by the proportion of population over 65 years in that sector. This study was approved by the Ethical Review Committee, Faculty of Medical Sciences, University of Sri Jayewardenepura.

\section{Definition of a fall}

A fall was defined as an event when a person comes to rest unintentionally on the ground or other lower level, without any extrinsic force (e.g. forcefully pushed down, knocked down by a car) [3, 4].

\section{Baseline assessment}

Socio-demographic and factors associated with falls were obtained by an interviewer administered questionnaire. Interviews were conducted at participants' residence and in the cognitively impaired, information was obtained from family members. Data collection was conducted by three pre-intern medical officers helped by the field assistants who were selected from the same cluster.

Disability was assessed using the WHO Disability Assessment Schedule II (WHODAS II) [12,13]. Participants were categorised as disabled if they scored above the 75th percentile of the baseline population. The MiniMental State Examination was performed if the participant showed features of cognitive impairment or was informed to be so by their relatives $[14,15]$. The Timed Up and Go Test was used to assess balance and gait [16]. The individuals were instructed to rise from a straight backed chair, walk three meters, turn, come back and sit. This was timed. It was performed twice, which included the practice test. Ability to come back and sit in less than 20 seconds was considered healthy. Participants were followed up for four months. All falls were recorded in a diary.

\section{Nested case control study}

Cases were participants with falls $(\mathrm{n}=151)$ while two controls $(n=302)$ per case were selected from participants who did not have a history of falls. Biological, behavioural and environmental risk factors were assessed by a separate interviewer administered questionnaire.

Biological factors identified were diseases including mental diseases, as reported by the participant, family member or extracted from the clinical records. Vision was checked using a pocket Snellen's chart, held at two meters from the eye with the participant seated. Visual acuity less than 6/60 in both eyes was considered poor [11]. Visible lesions in the foot (ankle joint and distal) such as ulcers, cellulites, oedema and deformities in toes were noted.

Level of physical activity was assessed by physical activity index (PAI) calculated by summation of number of hours spent in different activities multiplied by a weighting factor based on the estimated oxygen consumption required to perform each activity. PAI less than 29 was considered inactive [11]. Environmental factors were assessed using observations of the investigators. Living standards of the study participants were assessed by standards of living index (SLI) [17]. Source of drinking water, type of toilet facilities, floor material, and ownership of a radio, television, refrigerator and a vehicle were scored and added up.

\section{House risk factors}

House risk factors identified were obstacles, poor light and slippery surfaces in different areas of the house and the garden $[18,19]$. A House Risk Index (HRI) was developed by adding up the scores. Houses were categorized in to two groups (high risk and low risk) based on the 75th percentile of the HRI in the control group.

\section{Validity questionnaires}

No screening tool has been rigorously validated across countries to assess falls among the elderly [20]. Questionnaires for this study were developed by investigators and the face, content and consensual validity were assessed by a multi-disciplinary panel of experts consisting of specialists in surgery, medicine, community medicine, orthopaedics and rheumatology. Reliability of questionnaires was assessed by test-retest method.

\section{Data analysis}

Data were entered and analysed using the Statistical Package for Social Studies. Risk factors for falls were determined by calculating odds ratios. Bivariate analyses 
of socio economic, biological, behavioural and environmental factors were performed. Binomial logistic regression analysis was done to control for the possible effects of confounding. Attributable risk (AR\%) was calculated using the odds ratios derived, to estimate the proportion of falls among the exposed that was attributable to an exposure [21].

\section{Results}

\section{Baseline survey}

Ten eligible persons could not be enrolled due to inability to contact or refusal of consent (non-response rate of $0.8 \%$ ). However, cluster was extended until the required number of participants was enrolled. The sample was representative of the population over 65 years Colombo district in terms of age, sex and sector distribution ( $p>0.05$ ). The proportion of people over 65 years of age in Colombo district who live in the urban sector was $60 \%(n=89,454)$ and in the rural sector $40 \%$ $(n=56,949)$. According to that proportion 24 clusters from urban sector were and 16 clusters from rural sector included.

As presented in Table 1, majority of the participants was females $(57 \%, n=684)$. Mean age of study sample was 71.4 years (SD 6.8) with a range of 65 - 99 years.

Table 1. Distribution of socio demographic and socio economic characteristics of the study sample

\begin{tabular}{|c|c|c|c|c|c|c|c|}
\hline \multirow[t]{2}{*}{ Characteristic } & \multicolumn{2}{|c|}{$\begin{array}{l}\text { Female } \\
(n=684)\end{array}$} & \multicolumn{2}{|c|}{$\begin{array}{c}\text { Male } \\
(n=516)\end{array}$} & \multicolumn{2}{|c|}{$\begin{array}{c}\text { Total } \\
(n=1200)\end{array}$} & \multirow[t]{2}{*}{$\begin{array}{c}\text { Significance } \\
\qquad(d f=1)\end{array}$} \\
\hline & Number & $\%$ & Number & $\%$ & Number & $\%$ & \\
\hline \multicolumn{8}{|l|}{ Age } \\
\hline 65 - 74 years & 477 & 69.7 & 348 & 67.4 & 825 & 68.8 & $\chi^{2}=0.721$ \\
\hline$\geq 75$ years & 207 & 30.3 & 168 & 32.6 & 375 & 31.2 & $\mathrm{p}=0.396$ \\
\hline \multicolumn{8}{|l|}{ Sector } \\
\hline Urban & 409 & 59.8 & 311 & 60.3 & 720 & 60.0 & $\chi^{2}=0.028$ \\
\hline Rural & 275 & 40.2 & 205 & 39.7 & 480 & 40.0 & $\mathrm{p}=0.867$ \\
\hline \multicolumn{8}{|l|}{ Ethnicity } \\
\hline Sinhalese & 550 & 80.4 & 408 & 79.1 & 958 & 79.8 & $\chi^{2}=0.328$ \\
\hline Tamil* & 77 & 11.3 & 61 & 11.8 & 138 & 11.5 & $\mathrm{p}=0.567$ \\
\hline Muslim* & 54 & 7.9 & 38 & 7.4 & 92 & 7.7 & \\
\hline Others* & 3 & 0.4 & 9 & 1.7 & 12 & 1.0 & \\
\hline \multicolumn{8}{|l|}{ Religion } \\
\hline Buddhism & 513 & 75.0 & 390 & 75.6 & 903 & 75.2 & $\chi^{2}=0.053$ \\
\hline Hinduism* & 43 & 6.3 & 26 & 5.0 & 69 & 5.8 & $\mathrm{p}=0.818$ \\
\hline Islam* & 57 & 8.3 & 38 & 7.4 & 95 & 7.9 & \\
\hline Christianity* & 71 & 10.4 & 62 & 12.0 & 133 & 11.1 & \\
\hline \multicolumn{8}{|l|}{ Marital Status } \\
\hline Married & 368 & 53.8 & 392 & 76.0 & 760 & 63.3 & $\chi^{2}=62.24$ \\
\hline Never married* & 27 & 3.9 & 16 & 3.1 & 43 & 3.6 & $\mathrm{p}=0.000$ \\
\hline Previously married* & 289 & 42.3 & 108 & 20.9 & 397 & 33.1 & \\
\hline \multicolumn{8}{|l|}{ Living arrangement } \\
\hline Lived alone & 51 & 7.5 & 16 & 3.1 & 67 & 5.6 & $\chi^{2}=10.584$ \\
\hline Lived with somebody & 633 & 92.5 & 500 & 96.9 & 1133 & 94.4 & $\mathrm{p}=0.001$ \\
\hline \multicolumn{8}{|l|}{ Level of education } \\
\hline Up to Year 5 & 304 & 44.4 & 185 & 35.8 & 489 & 40.8 & $\chi^{2} 2=8.992$ \\
\hline Year 6 and above & 380 & 55.6 & 331 & 64.2 & 711 & 59.2 & $\mathrm{P}=0.003$ \\
\hline \multicolumn{8}{|c|}{ Current employment status } \\
\hline Employed & 41 & 6.0 & 67 & 13.0 & 108 & 9.0 & $\chi^{2}=17.548$ \\
\hline Not employed & 643 & 94.0 & 449 & 87.0 & 1092 & 91.0 & $\mathrm{P}=0.000$ \\
\hline \multicolumn{8}{|l|}{ Monthly income (Rs) } \\
\hline No income* & 486 & 71.4 & 276 & 53.6 & 762 & 63.7 & $\chi^{2}=27.437$ \\
\hline$<10000^{*}$ & 131 & 19.3 & 136 & 26.4 & 267 & 22.3 & $\mathrm{P}=0.000$ \\
\hline$\geq 10000$ & 64 & 9.3 & 103 & 20.0 & 167 & 14.0 & \\
\hline
\end{tabular}

Missing value; female $=3$, male $=1$

${ }^{*}$ Categories were amalgamated in calculating $\chi^{2}$. 


\section{Incidence of falls}

Out of 1200 participants, 310 (25.8\%) had falls within the previous year. Five hundred and eighty three (48.6\%) perceived falls among the elderly as a significant health problem. Fifteen participants (1.3\%) were lost to follow up. Majority of them were males $(53.3 \%, n=8)$, aged 65 to 69 years $(53.3 \%, \mathrm{n}=8)$ and were from the urban sector $(60 \%$, $\mathrm{n}=7)$. Out of 1185 participants, 152 (12.8\%) had falls during the four month prospective follow up period. Twenty two (14.5\%) had more than one fall (ie. They had recurrent falls). Total number of falls was 194 . The incidence rate of falls was 491 per 1000 person years (95\% CI 448-536). Incidence rate of falls in females was 515 per 1000 person years (95\% CI 469-561) and in males 462 per 1000 person years (95\% CI 420-504). Incidence rates in 65 to 69 years, 70 to 74 years and above 75 years age groups were 360 (95\% CI 328-392), 458 (95\% CI 417-499) and 691 (95\% CI 629-753) per 1000 person years respectively. Participants who were 75 years or above were nearly twice as likely to have a fall (Table 2).

Table 2. Association between falls and socio-demographic factors

\begin{tabular}{|c|c|c|c|c|c|}
\hline \multirow[t]{2}{*}{ Related factor } & \multicolumn{2}{|c|}{$\begin{array}{c}\text { Cases } \\
(n=151)\end{array}$} & \multicolumn{2}{|c|}{$\begin{array}{l}\text { Controls } \\
(n=302)\end{array}$} & \multirow[t]{2}{*}{$\begin{array}{c}\text { OR } \\
(95 \% C I)\end{array}$} \\
\hline & Number & $\%$ & Number & $r \%$ & \\
\hline \multicolumn{6}{|l|}{ Age } \\
\hline$\geq 75$ years & 67 & 44.4 & 91 & 30.1 & 1.85 \\
\hline$<75$ years & 84 & 55.6 & 211 & 69.9 & $(1.23-2.77)$ \\
\hline \multicolumn{6}{|l|}{ Sex } \\
\hline Female & 91 & 60.3 & 173 & 57.3 & 1.13 \\
\hline Male & 60 & 39.7 & 129 & 42.7 & $(0.76-1.68)$ \\
\hline \multicolumn{6}{|l|}{ Ethnicity } \\
\hline $\begin{array}{l}\text { Tamils, Muslims } \\
\text { and Burgers }\end{array}$ & 31 & 20.5 & 69 & 22.8 & 0.87 \\
\hline Sinhalese & 120 & 79.5 & 233 & 77.2 & $(0.54-1.41)$ \\
\hline \multicolumn{6}{|l|}{ Marital status } \\
\hline \multicolumn{6}{|l|}{ Unmarried, widowed } \\
\hline or divorced & 62 & 41.1 & 110 & 36.4 & 1.22 \\
\hline Married & 89 & 58.9 & 192 & 63.6 & $(0.82-1.812)$ \\
\hline \multicolumn{6}{|l|}{ Educational level } \\
\hline Grade 5 or below & 66 & 43.7 & 127 & 42.1 & 1.07 \\
\hline Beyond grade 5 & 85 & 56.3 & 175 & 57.9 & $(0.72-1.59)$ \\
\hline \multicolumn{6}{|c|}{ Employment status } \\
\hline Not employed & 140 & 92.7 & 269 & 89.1 & 1.56 \\
\hline Employed & 11 & 7.3 & 33 & 10.9 & $(0.77-3.18)$ \\
\hline \multicolumn{6}{|c|}{ Living arrangement } \\
\hline Lived alone & 11 & 7.3 & 12 & 4.0 & 1.90 \\
\hline Lived with someone & 140 & 92.7 & 290 & 96.0 & $(0.82-4.41)$ \\
\hline
\end{tabular}

Presence of more than two chronic diseases, dizziness, history of falls within the previous year and poor mobility had statistically significant association with falls. Disabled participants had a higher risk of falls compared to non-disabled (Table 3).

Table 3. Association between falls and biological factors

\begin{tabular}{lcrc}
\hline Biological factor & $\begin{array}{c}\text { Controls } \\
(n=151)\end{array}$ & OR \\
& Number \% $\%$ & Number \% & \\
& & \\
\end{tabular}

$>2$ chronic Diseases

$\begin{array}{lrrrrr}\text { Present } & 76 & 50.3 & 122 & 40.4 & \mathbf{1 . 5 0} \\ \text { Absent } & 75 & 49.7 & 180 & 59.6 & \mathbf{( 1 . 0 1 - 2 . 2 2 )} \\ & & & & & \\ \text { Hypertension } & & & & & \\ \begin{array}{l}\text { Present } \\ \text { Absent }\end{array} & 77 & 51.0 & 144 & 47.7 & 1.14 \\ & 74 & 49.0 & 158 & 52.3 & (0.77-1.69)\end{array}$

Ischemic Heart disease

$\begin{array}{llllll}\text { Present } & 26 & 17.2 & 53 & 17.5 & 0.98\end{array}$

$\begin{array}{llllll}\text { Absent } & 125 & 82.8 & 249 & 90.7 & (0.58-1.64)\end{array}$

Stroke

$\begin{array}{lrrrrr}\text { Present } & 16 & 10.6 & 28 & 9.3 & 1.16\end{array}$

$\begin{array}{llllll}\text { Absent } & 135 & 89.4 & 274 & 90.7 & (0.61-2.22)\end{array}$

Diabetes

$\begin{array}{llllll}\text { Present } & 40 & 26.5 & 66 & 21.9 & 1.29\end{array}$

$\begin{array}{lrrrrr}\text { Absent } & 111 & 73.5 & 236 & 78.1 & (0.82-2.03)\end{array}$

Osteoporosis

$\begin{array}{lrrrrr}\text { Present } & 9 & 6.0 & 17 & 5.6 & 1.06\end{array}$

$\begin{array}{llllll}\text { Absent } & 142 & 94.0 & 285 & 94.4 & (0.46-2.44)\end{array}$

Epilepsy

Present

Absent

13

$\begin{array}{lll}8.6 & 13 \quad 4.3\end{array}$

2.09

Dizziness

Present

Absent

63

41.7

$95 \quad 31.5$

1.56

Arthritis

Present

51

33.8

$94 \quad 31.1$

1.13

Absent

100

$208 \quad 68.9$

(0.74-1.71)

Mental diseases

Presen

23

15.2

$\begin{array}{ll}28 & 9.3\end{array}$

1.76

Absent

128

$274 \quad 90.7$

(0.98-3.17)

Urinary incontinence

Present

12

7.
92.

$17 \quad 5.6$

1.45

Absent

139

2.1

$285 \quad 94.4$

(0.67-3.11) 
Falls within previous year

$\begin{array}{lrrrrr}\text { Present } & 87 & 57.6 & 74 & 24.5 & \mathbf{4 . 1 9} \\ \text { Absent } & 64 & 42.4 & 228 & 75.5 & \mathbf{( 2 . 7 6 - 6 . 3 5 )} \\ & & & & & \\ \begin{array}{l}\text { Foot disorder } \\ \text { Present }\end{array} & 56 & 37.1 & 93 & 30.8 & 1.33 \\ \begin{array}{l}\text { Absent } \\ \text { Timed Up and Go test }\end{array} & 95 & 62.9 & 209 & 69.2 & (0.88-2.00) \\ \begin{array}{l}\text { Poor mobility } \\ \text { (> } 20 \text { seconds) }\end{array} & 33 & 24.4 & 34 & 11.8 & \mathbf{2 . 4 5} \\ \begin{array}{l}\text { Good mobility } \\ \leq 20 \text { seconds }\end{array} & 102 & 75.6 & 255 & 88.2 & \\ \begin{array}{l}\text { Vision } \\ \begin{array}{l}\text { Poor vision } \\ (<6 / 60)\end{array}\end{array} & 65 & 43.0 & 100 & 33.9 & 1.47 \\ \begin{array}{l}\text { Good vision } \\ (>6 / 60)\end{array} & & & & & (0.99-2.22) \\ & 86 & 57.0 & 195 & 66.1 & \end{array}$

Mini Mental

State Examination

Cognitive

1.15

impairment

(score $<24$ )

$\begin{array}{llll}4 & 2.6 & 7 & 2.3\end{array}$

No cognitive

impairment

(score $\geq 24$ )

$\begin{array}{llll}147 & 97.4 & 295 & 97.7\end{array}$

Disability

Disabled

(disability

score $>75 \%$ )

$\begin{array}{llll}60 & 40.8 & 60 & 20.1\end{array}$

(1.77-4.22)

Non disabled

(disability

score $\leq 75 \%$ )

$\begin{array}{llll}87 & 59.2 & 238 & 79.9\end{array}$

(0.33-3.98)
Table 4. Association between falls and biological factors

\begin{tabular}{lccc}
\hline Biological factor & $\begin{array}{c}\text { Cases } \\
(n=151)\end{array}$ & $\begin{array}{c}\text { Controls } \\
(n=302)\end{array}$ & $\begin{array}{c}\text { OR } \\
(95 \% \text { CI })\end{array}$ \\
Number \% $\%$ & Number \% & \\
\hline
\end{tabular}

Thinks falls as a significant problem

$\begin{array}{lrrrrr}\text { No } & 162 & 53.6 & 78 & 51.7 & 1.08\end{array}$

$\begin{array}{lrrrrr}\text { Yes } & 140 & 46.4 & 73 & 48.3 & (0.73-1.60)\end{array}$

Taking more than

4 types of medicines

$\begin{array}{lrrrrr}\text { Present } & 253 & 83.8 & 125 & 82.8 & 1.07\end{array}$

$\begin{array}{llllll}\text { Absent } & 49 & 16.2 & 26 & 17.2 & (0.63-1.81)\end{array}$

Intake of alcohol

$\begin{array}{lrrrrr}\text { Present } & 268 & 88.7 & 138 & 91.4 & 0.74\end{array}$

$\begin{array}{llllll}\text { Absent } & 34 & 11.3 & 13 & 8.6 & (0.38-1.45)\end{array}$

Smoking

$\begin{array}{lrrrrr}\text { Present } & 276 & 91.4 & 143 & 94.7 & 0.60\end{array}$

$\begin{array}{lrrrrr}\text { Absent } & 26 & 8.6 & 8 & 5.3 & (0.26-1.35)\end{array}$

Betel chewing

$\begin{array}{llllll}\text { Present } & 249 & 82.5 & 128 & 84.8 & 0.84\end{array}$

$\begin{array}{lrrrrr}\text { Absent } & 53 & 17.5 & 23 & 15.2 & (0.50-1.44)\end{array}$

Physical activity level

Active (PAI > 29) $214 \quad 70.9 \quad 105 \quad 69.5 \quad 1.07$

$\begin{array}{lrrrr}\text { Inactive }(\mathrm{PAI}<29) 88 & 29.1 & 46 & 30.5 & (0.7-1.63)\end{array}$

Duration of sleep

$\begin{array}{lrrrrr}<6 \text { hours } & 271 & 89.7 & 138 & 91.4 & 0.82\end{array}$

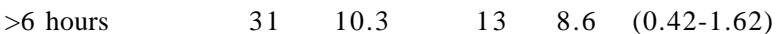

Attention to correct medical problems

$\begin{array}{lrrrrr}\text { Poor } & 218 & 72.2 & 109 & 72.2 & 0.58\end{array}$

$\begin{array}{lrrrrr}\text { Satisfactory } & 84 & 27.8 & 42 & 27.8 & (0.32-1.08)\end{array}$

Risk taking behaviours

$\begin{array}{lrrrrr}\text { Present } & 254 & 84.1 & 136 & 90.1 & 0.58 \\ \text { Absent } & 48 & 15.9 & 15 & 9.9 & (0.32-1.08)\end{array}$

Participants who lived in houses with a high risk level had significantly higher risk of falls than the participants who lived in houses with a low risk level (Table 4).

Variables entered into the first step of logistic regression model included age, presence of more than two chronic diseases, epilepsy, dizziness, poor vision, poor mobility, disability, risk taking behaviours and high house risk level.

Binominal logistic regression was performed to assess the factors associated with falls. The final model containing all predictors was statistically significant $\left(\chi^{2}=52.07, \mathrm{n}=453, p<0.001\right.$ ), indicating that the model was able to distinguish between factors associated with falls among elderly. Falls in the previous year, high disability level and high house risk level were significantly associated with falls. Attributable risk percent for falls in the previous year was 79\%, high disability level 51\% and high housing level $40 \%$.
Living standards

$\begin{array}{lrrrrr}\text { Low } & 25 & 16.6 & 41 & 13.6 & 1.26\end{array}$

$\begin{array}{llllll}\text { High or medium } & 126 & 83.4 & 261 & 86.4 & (0.73-2.17)\end{array}$

House risk level

$\begin{array}{llllll}\text { Low } & 94 & 62.3 & 223 & 73.8 & (1.13-2.60)\end{array}$

\section{Discussion}

Incidence of falls was 491 per 1000 person years. Percentage of people who had falls per year (38.4\%) was higher than the 28-35\% reported by the WHO Global Report and 23\% reported by a hospital based study in the district of Colombo, for the corresponding age group [3, $10]$. These differences may be due to recall bias in the retrospective data collection in these two studies.

$\begin{array}{lrrrrr}\text { High } & 57 & 37.7 & 79 & 26.2 & 1.71\end{array}$


Table 5. Logistic regression model (final step) for identification

of risk factors for falls

\begin{tabular}{|c|c|c|c|c|c|c|c|c|}
\hline \multirow[t]{2}{*}{ Variable } & \multirow[t]{2}{*}{$B$} & \multirow[t]{2}{*}{ S.E. } & \multirow[t]{2}{*}{ Wald } & \multirow[t]{2}{*}{$d f$} & \multirow[t]{2}{*}{$P$} & \multirow[t]{2}{*}{ Adjusted $O R$} & \multicolumn{2}{|c|}{$95 \% C I$} \\
\hline & & & & & & & Lower & Upper \\
\hline Falls in previous year & 1.540 & 0.235 & 43.125 & 1 & 0.000 & 4.67 & 2.95 & 7.39 \\
\hline Poor vision & 0.444 & 0.255 & 3.042 & 1 & 0.081 & 1.56 & 0.95 & 2.57 \\
\hline High disability level & 0.714 & 0.276 & 6.691 & 1 & 0.010 & 2.04 & 1.19 & 3.51 \\
\hline High house risk level & 0.516 & 0.244 & 4.463 & 1 & 0.035 & 1.68 & 1.04 & 2.70 \\
\hline Constant & -1.882 & 0.213 & 77.898 & & 0.000 & 0.15 & & \\
\hline
\end{tabular}

Participants who had falls in the previous year had more than fourfold risk of having another fall. In a systematic review of 74 prospective studies investigating risk factors for falls among elderly, the strongest associations were found for history of falls (OR $=2.8$ ) [22]. Disabled participants had a twofold risk of falls than non-disabled participants. By eliminating causes for high disability level, $51 \%$ of falls can be prevented. A systematic review of 129 studies on risk factors for falls, found that difficulties in activities of daily living doubled the risk of falling [23]. Elderly living in houses with high risk levels had a higher risk of falling $(\mathrm{OR}=1.6)$. Accordingly $40 \%$ of falls in the elderly can be prevented by eliminating the high house risk level. Several studies have reported home safety assessment and modification interventions as effective in reducing risk of falling $(\mathrm{OR}=0.88)$ [9].

Some risk factors significant in the bivariate analysis were not significant after adjusting for confounding variables. They included age, presence of more than two chronic diseases, dizziness and mobility level. The significant association between these factors and falls among participants observed in the bivariate analysis could be due to the confounding effect of disability which is associated with all these factors.

In conclusion, the high incidence of falls reported in this study and identification of preventable risk factors emphasise the importance of preventing falls.

\section{Acknowledgements}

Baseline data collection of the study was funded by the Education, Training and Research Unit of the Ministry of Health, Sri Lanka.

\section{References}

1. Siddhisena KAP. Demography of aging in Sri Lanka. In: Aging Population in Sri Lanka. United Nations Population Fund 2004; 8-43.
2. Leveille SG, Kiel DP, Jones RN, et al. The MOBILIZE Boston Study: design and methods of a prospective cohort study of novel risk factors for falls in an older population. BMC Geriatrics 2008; 8: 16.

3. WHO Global Report on falls prevention in older age. Geneva: World Health Organization, 2007.

4. Chu LW, Chi I, Chiu AY. Incidence and predictors of falls in Chinese elderly. ANNALS Academy of Medicine Singapore 2005; 34: 60-72.

5. Krishnaswamy B, Gnanasambandam. Falls in Older People, National/Regional Review, India, 2011 [cited 2011 June 15]; Available from: www.who.int/ageing/projects/SEARO.pdf

6. Tonarelli L. Consequences of falls in the elderly. 2010 [cited 2011 June 15]; Available from: http:www.suite101.com/ content/consequences-of-falls-in-elderl-a204515.

7. Jarvinen TLN, Sievanen H, Khan KM et al. Shiftin the focus in fracture prevention from osteoporosis to falls. British Medical Journal 2008; 336: 124-6.

8. Berg WP, Alessio HM, Mills EM, Tong C. Circumstances and consequences of falls in independent community dwelling older adults. Age and Aging 1997; 26: 261-8.

9. Gillespie LD, Robertson MC, Gillespie WJ, et al. Interventions for preventing falls in older people living in the community. The Cochrane Database of Systematic Reviews Library 2012; 9: CD 007146.

10. Weerasuriya N, Jayasinghe S. A preliminary study of the hospital-admitted older patients in a Sri Lankan tertiary care hospital. Ceylon Medical Journal 2005; 50: 18-9.

11. Pannilahetti N. A study on risk factors of hip fractures among elderly in Colombo district and subjective burden on caregivers. Thesis in Community Medicine, Post Graduate Institute of Medicine, University of Colombo, 2003.

12. Schlesselman JJ, Stolley PD. Case-control Studies - Design, Conduct, Analysis, New York: Oxford University Press, 1982.

13. World Health Organization Disability Assessment Schedule II (WHODAS II); Development, Psychometric testing and Applications. Geneva: World Health Organization, 2007.

14. Samarasekara SD. Disability, psychological and socioeconomic aspects, morbidity control and use of services of 
patients with chronic manifestations of filarial lymphoedema in an area endemic for lymphatic filariasis. Theses in Community Medicine, Post Graduate Institute of Medicine, University of Colombo, 2009.

15. Fostein MF, Folstein SE, McHugh PR. "Mini-mental state”. A practical method for grading the cognitive state of patients for the clinician. Journal of Psychiatric Research 1975; 12: 189-98.

16. de Silva HA, Gunatilake SB. Mini mental status examination in Sinhalese: a sensitive test to screen for dementia in Sri Lanka. International Journal of Geriatric Psychiatry 2002; 17: 134-9.

17. Podsiadlo D, Richardson S. The timed "Up and Go": a test of basic functional mobility for frail elderly persons. Journal of the American Geriatrics Society 1991; 39: 142-8.

18. Munasinghe L. Prevalence and correlates of physical abuse within marriage in a cohort of pregnant women. Theses in
Community Medicine, Post Graduate Institute of Medicine, University of Colombo, 2002.

19. Minnesota Falls Prevention Checklist; Check your housePrevent falls. Minnesota Safety Council, 2009 [cited 2009 June 18] Available from: http://www.mnsafetycouncil.org/ seniorsafe/falls/index.cfm?SO=1

20. Hand Book for Elderly. Sri Lanka: Department of Social Services, 2001.

21. What are the main risk factors for falls amongst older people and what are the most effective interventions to prevent these falls? Health Evidence Network, World Health Organization, 2004.

22. Hennekens $\mathrm{CH}$, Buring JE. Epidemiology in Medicine, 2nd ed. Boston/Toronto: Little Brown and company, 1987.

23. Silviaa D, Ersiliaa L, Francescaa L, et al. Risk Factors for Falls in Community-dwelling Older People: A Systematic Review and Meta-analysis. Epidemiology 2010; 21: 658-68.

\title{
Prevalence of enterobiasis among primary school children in Ragama, Sri Lanka
}

\author{
N K Gunawardena, T N Chandrasena, N R de Silva
}

(Index words: Enterobius vermicularis, prevalence, school children, Sri Lanka, helminth)

\begin{abstract}
Objectives To determine the prevalence of enterobiasis among school children in Ragama Medical Officer of Health $(\mathrm{MOH})$ region and the association between clinical features, potential risk factors and infection status.

Design Cross sectional study.

Setting School based.

Participants 260 school children aged 5-7 years, attending five state schools in the Ragama $\mathrm{MOH}$ region.

Main outcome measures Prevalence of Enterobius vermicularis infection as diagnosed using adhesive cellophane tapes on the perianal skin on 2 consecutive days.

Results The overall prevalence of enterobiasis was 38\%. The risk factors significant on a univariate analysis were male gender, maternal under-education, non-permanency of paternal employment, more household members, more siblings in a family, more persons sleeping with an index child and lack of recent
\end{abstract}

deworming. On a multivariate model more household members, more children in a household, more persons sleeping with the index child, non-permanency of paternal employment and lack of recent deworming were significantly associated with infection. None of the clinical manifestations evaluated (peri-anal itching, insomnia, abdominal pain, and enuresis) showed a significant association with enterobiasis.

Conclusions Enterobiasis is highly prevalent among primary school children in Ragama.

Ceylon Medical Journal 2013; 58: 106-110

\section{Introduction}

Enterobiasis, considered one of the commonest childhood intestinal nematode infections, has a worldwide distribution. The important routes of transmission are 